Osoba i doświadczenie mistyczne (4) „Filozofia Chrześcijańska” 16 (2019), s. 123-138

\author{
ADAM WYSOCKI \\ Uniwersytet im. Adama Mickiewicza w Poznaniu \\ Wydział Teologiczny
}

\title{
Rozwój duchowy z perspektywy zagadnienia świadomości. Zarys problematyki
}

Refleksja podjęta w niniejszym artykule ma na celu charakterystykę rozwoju duchowego rozpatrywaną od strony zagadnienia świadomości i stanowi próbę wskazania obszarów wzrostu, potencjalnej zmiany, jaka musi się dokonać, ujętą z tej właśnie perspektywy. W swoim artykule dotyczącym rozwoju duchowego Paweł Socha wskazuje, że problematyka rozwoju duchowego jest bardzo szeroka i dotyczy wielu aspektów związanych, przede wszystkim, z życiem wewnętrznym człowieka. Spośród wymienionych elementów skupionych w obrębie jego struktury ontycznej świadomość w kontekście rozważanego problemu stanowi, jak się wydaje, najważniejszy element. Wspomniany autor, dokonując analizy interesujących nas kwestii, zauważa, że: „Duchowy świat człowieka jawi się na scenie świadomości. Teatr jego psychiki obejmuje zapewne i kulisy (podświadomość), i publiczność (ogląd oczyma innych jako podstawa tzw. informacji zwrotnych o sobie samym). Jednak scena, a raczej świadomie wydobyty z niej reflektorem jaźni fragment akcji z podmiotem w roli głównej, ma tu kluczowe znaczenie" . Cytowany autor akcentuje znaczenie samoświadomości i przechodząc do konkluzji, podkreśla jej szczególną rolę w rozwoju duchowym.

Tym jednak, co najbardziej różni człowieka od innych istot, jest chyba samoświadomość. Można zaryzykować tezę, że samoświadomość stanowi warunek konieczny życia duchowego. Dopiero bowiem spojrzenie na samego siebie umożliwia jednostce ujrzenie siebie w relacji do świata i innych ludzi, „ujrzenie”

${ }^{1}$ P. Socha, Psychologia rozwoju duchowego, w: Duchowy rozwój człowieka, red. P. Socha, Kraków 2000, s. 18. 
własnych doznań i przeżyć, samoobserwację, samokontrolę, samorozwój [...] samoświadomość umożliwia jednostce konstatację własnej ograniczoności. [...] W tym sensie właśnie samoświadomość można traktować jako jądro życia duchowego ${ }^{2}$.

Według powyższego zagadnienie świadomości jest czymś niezbywalnym i inherentnie związanym z rozwojem duchowym. Ze względu na charakter problematyki rozwoju duchowego obydwie kwestie muszą się ze sobą łączyć, ponieważ aby przeobrażenie wnętrza, jakakolwiek zmiana sposobu bycia, była trwała, musi być dokonana świadomie lub w świetle świadomości oraz sama postulowana zmiana musi znaleźć tu także swoje odzwierciedlenie.

Pojęcie rozwoju duchowego nie jest całkowicie jednoznaczne, a także zmieniało swoje znaczenie na przestrzeni wieków i było blisko związane z pojęciem duchowości. Należy zatem dokonać krótkiej charakterystyki obydwu pojęć oraz współczesnego ich rozumienia.

\section{Rozwój duchowy a duchowość w tradycyjnym i współczesnym rozumieniu}

Zagadnienie rozwoju duchowego jest czymś złożonym, ma bowiem wiele odniesień i skojarzeń. Sformułowanie „rozwój duchowy”, mówiąc ogólnie, wskazuje na pewien rodzaj aktywności człowieka, który tworzy określony światopogląd. Sformułowanie to wskazuje także na pogłębianie się pewnych wartości powiązanych najczęściej z jakąś denominacją religijną, która ma na celu zmianę lub bardziej przemianę, wzrost własności powszechnie przyjętych za pozytywne, jednak występujących jeszcze w sposób niepełny ${ }^{3}$. Zagadnienie rozwoju duchowego należy do kategorii „duchowości” i stanowi jej istotny element. Józef Baniak stwierdza, że: „Zagadnienie duchowości religijnej ściśle łączy się z kwestią duchowego postępu człowieka na drodze jego dążenia do osobistej doskonałości” i dodaje dalej, precyzując: „Taki postęp ma niekiedy charakter religijny lub niereligijny"4.

Wspomniany autor tworzy typologię zagadnienia, dokonując przeglądu różnych ujęć, wskazuje, że istnieją trudności z jednoznacznym określeniem zjawiska, zaś różne typy ujawniają swój mniejszy lub większy związek

2 Tamże, s. 19.

3 A. Wysocki, Rozwój duchowy czlowieka w świetle pogladów św. Jana od Krzyża, w: Wychowanie do dialogu, red. K. Rędziński, Częstochowa 2008, s. 69.

${ }^{4}$ J. Baniak, Wprowadzenie. Wielowymiarowość i konteksty kulturowe duchowości religijnej a inne formy duchowości, w: Duchowość religijna jako droga wewnętrznego doskonalenia wspótczesnego czlowieka zachodniego chrześcijaństwa, red. J. Baniak, Torun 2012, s. 25. 
z religijnością. Powód definiowania duchowości w taki właśnie sposób znajduje uzasadnienie $\mathrm{w}$ tym, że zagadnienie to było jak dotąd związane z refleksją na gruncie danego systemu religijnego oraz na obszarze oddziaływania myśli europejskiej. Herbert Vorgrimler zauważa, że w chrześcijaństwie słowo „,duchowość” obecnie coraz częściej wypiera dawniejszy termin „pobożność”. Ten drugi dotyczy różnego rodzaju praktyk mających na celu kształtowanie osobowości w świetle wiary religijnej, zaś termin „duchowość” wskazuje na sposoby działania Ducha 5 . Pochodzi od łacińskiego spiritualis, czyli 'umysłowy', 'duchowy' (gr. pneumatikos), choć sam czasownik spirare znaczy 'oddychać' i odnosi się do życia. Zmiana ta jest związana z teologią wczesnego chrześcijaństwa. Już u św. Pawła terminy pneuma i pneumatikos stoją w opozycji do sarks ('ciało') i sarkikos ('cielesny') nie w sensie wskazania na przeciwieństwo lub odmienność dotyczącą różnicy w sensie ontologicznym, lecz sposobu bycia. Człowiek duchowy to taki, który podporządkowuje swoje życie temu, co duchowe, działa z poruszeń Ducha Świętego, natomiast życie człowieka cielesnego, czyli zmysłowego, kształtuje się w opozycji do Ducha Świętego ${ }^{6}$. Narracja ta ujawnia głębokie zakotwiczenie tego pierwszego sposobu bycia w danej denominacji religijnej poprzez bezpośrednie odwołanie do sacrum religijnego ${ }^{7}$. Paweł Socha zauważa, że są to ,przejawy dążeń do przekraczania granic ludzkiej egzystencji wynikające $\mathrm{z}$ chęci przezwyciężania śmierci i wszelkich ograniczeń wynikających z niedoskonałości fizycznej, psychicznej czy społecznej”».

Z tego względu duchowość jest obarczona specyficznym sposobem postrzegania świata zawierającym określone komponenty, które u swojej podstawy czerpią z tego, co charakterystyczne dla religii. Ma pewien zdefiniowany cel oraz postuluje działanie zmierzające do jego osiągnięcia, które można nazwać rozwojem duchowym. Sam rozwój duchowy nominalnie już mówi o efektach, pośrednio wskazując na przejście z jakiegoś stanu, sposobu bycia człowieka, do innego. Niemniej, by taka zmiana mogła się dokonać, wpierw definiuje się sytuację obecną jako niewłaściwą i uwarunkowaną w stosunku do jakiejś sytuacji właściwej, ku której się dąży i która daje ostateczne spełnienie. Wynika ona zresztą z założonego celu w systemie, będącego przedmiotem religijnym, czyli sacrum. Z tego względu można powiedzieć, że aktywność prokurująca zmianę stanowi zasadniczy element tego, co się tyczy rozwoju duchowego oraz samej duchowości. Określenia wskazujące

${ }^{5}$ H. Vorgrimler, Nowy leksykon teologiczny, Wiara - Objawienie - Dogmat, thum. i oprac. T. Mieszkowski, P. Pachciarek, Warszawa 2005, s. 78.

${ }^{6}$ P. Moskal, Problematyka filozofii duchowości, w: Duchowość religijna jako droga wewnętrznego doskonalenia wspótczesnego człowieka zachodniego chrześcijaństwa, red. J. Baniak, Toruń 2012, s. 41.

7 Tamże.

${ }^{8}$ Cyt za: J. Baniak, Wprowadzenie. Wielowymiarowość i konteksty..., dz. cyt., s. 7. 
na zmianę mówią o przekraczaniu pewnych aktualnych uwarunkowań, czyli jakichś błędów poznawczych, niemożności sprostania zaleceniom kodeksu moralnego lub niepełnego posiadania określonych cech. Charakterystyka, jaką znajdujemy u tegoż autora, wskazuje na szereg ujęć, w których można zauważyć mniejszy lub większy związek z religią bądź też z wykorzystaniem uzasadnienia o charakterze religijnym.

Do czasów współczesnych duchowość była związana z jakimś systemem religijnym i polegała na określonej relacji do sacrum, czyli przedmiotu religijnego danego systemu. Rodzaj relacji jest zrelatywizowany, tzn. jest uzależniony od charakterystyki definicyjnej sacrum zawartej w danym systemie religijnym. W efekcie możemy wyróżnić ogólną typologię z tym związaną, która sprowadza się do trzech rodzajów:

- Typ legalistyczny - realizuje się poprzez posłuszeństwo świętemu prawu (jak hinduska rita czy judaistyczna Tora) zawartemu w świętych księgach oraz podporządkowanie się autorytetowi interpretatorów tych ksiąg. Celem jest utrzymanie sakralnego porządku, natomiast indywidualne dążenia duchowe mają mniejsze znaczenie.

- Typ aktywny - akcentuje przeżywanie treści religijnych wraz z nastawieniem na działanie wewnętrzne bądź zewnętrzne. W typie tym ma znaczenie osobisty stosunek do sacrum, natomiast działania religijno-społeczne schodzą na dalszy plan.

- Typ kontemplatywny - polega na izolowaniu się człowieka od świata zjawisk w bardziej efektywnym zmierzaniu do osiągnięcia sacrum, czyli w przypadku chrześcijaństwa do zjednoczenia z Bogiem. Ujawnia się $\mathrm{w}$ różnych formach mistyki w zależności od sposobu zdefiniowania przedmiotu religijnego'.

Zarysowane powyżej typy stanowią trzy aspekty jednego modelu duchowości, mianowicie duchowości religijnej, która realizuje bardziej tradycyjny sposób jej rozumienia, oraz związanej z nią kwestii rozwoju duchowego. Obecnie sytuacja uległa zmianie, ponieważ terminowi „duchowość” przypisuje się zdecydowanie szerszy zakres znaczeniowy i dlatego jest trudny do precyzyjnego określenia. Wypiera bowiem takie pojęcia jak „pobożność” czy „religijność”, jednocześnie wprowadzając takie terminy jak „bezbożność” i „świeckość”, zakładając przy tym, że jest możliwy duchowy rozwój człowieka poza religią $^{10}$. Jak pisze Józef Baniak, korzystając z opracowania Włodzimierza Pawluczuka, współcześnie duchowości można przypisać określone cechy, które wskazują na pewien ogólny trend z tym związany. W bardziej syntetycznym ujęciu zjawiska przedstawionego przez wspomnianego autora zagadnienie to,

\footnotetext{
9 Tamże, s. 18.

10 Tamże, s. 28.
} 
mając na uwadze przedmiot tu rozważany, można ująć za pomocą kilku punktów. Są nimi (1) odrzucenie antropomorficznie rozumianego Boga; (2) sacrum ma najczęściej charakter immanentny i bezosobowy; (3) zniesienie dualizmu ducha i materii oraz zwrot w kierunku koncepcji panteistycznych; (4) zainteresowanie odmiennymi stanami świadomości oraz środkami mogącymi je wywołać w sposób sztuczny; (5) wzrost znaczenia praktyk mających indywidualny charakter, które dokonują interioryzacji podmiotu (joga), próbują oddziaływać na rzeczywistość, wręcz ją kreować (magia) lub na różne sposoby odczytywać i dokonywać nowej interpretacji (astrologia, astrofizyka) ${ }^{11}$. Powyższy zestaw cech, choć przedstawiony w skrótowej formie, pozwala stwierdzić, że następuje osłabienie, redukcja lub nawet porzucenie „silnej” ontologii obecnej $\mathrm{w}$ religiach zinstytucjonalizowanych. To oznacza przejście do ontologii wieloznacznej i bardziej zrelatywizowanej, w której tym samym terminom przypisuje się już odmienny sens, a który to sens nie ma statusu ostatecznie ustalonego i łatwo podlega dalszej modyfikacji. Sprzyja temu obecna wielokulturowość oraz rozwój technologii i komunikacji powodujący wymianę myśli oraz wpływ azjatyckich koncepcji religijno-filozoficznych. Co za tym idzie, następuje przesunięcie celu religijnego i czynnika zbawczego z pozapodmiotowego do mieszczącego się w obrębie podmiotu, a i sama duchowość ma przez to bardziej autosoteriologiczny i poznawczy charakter. Tomasz Brzozowski, dokonując charakterystyki tego zagadnienia, trafnie zauważa, że:

Współczesna duchowość jest [...] głównie procesem sakralizacji jaźni. Towarzyszy mu najczęściej indywidualna droga prowadząca do sfery sacrum, przy czym sacrum niekoniecznie musi być ujmowane w kategoriach osobowych, ale może przejawiać się jako niezidentyfikowana siła lub moc od której zależy świat i ludzkość. Ma realną moc ingerowania w historię świata lub w życie człowieka ${ }^{12}$.

Problem tu rozważany wpisuje się zarówno w jeden, jak i drugi rodzaj duchowości, choć formalnie odnosi się bardziej do duchowości nieinstytucjonalnej, to w rzeczy samej dotyczy obydwu typów. Ogólnie rzecz ujmując, jakikolwiek rozwój duchowy, osadzony w konkretnej religijności lub poza

11 Por. tamże, s. 10-11.

${ }_{12}$ T.T. Brzozowski, Religijność czy duchowość? O strukturze przeżyć wewnętrznych człowieka, w: Duchowość religijna jako droga wewnętrznego doskonalenia wspótczesnego czlowieka zachodniego chrześcijaństwa, red. J. Baniak, Toruń 2012, s. 277. Należy zauważyć, że do czasów współczesnych pojęcie duchowości słabo odróżniało się od pojęcia religijności, a ostatecznie zrodziło się na zasadzie wyodrębniania się indywidualnych form religijności oraz większej akceptacji dla osobistych dróg zmierzania do sacrum, które mają wsparcie we współczesnych trendach pluralizmu kulturowego. Obecnie istnieje pewna tendencja, nie tylko do zdecydowanego odróżniania obu pojęć, ale wręcz przeciwstawiania sobie. Zob. M. Jarosz, Pojęcie duchowości w psychologii, w: Studia z psychologii w KUL, t. 16, red. O. Gorbaniuk i in., Lublin 2010, s. 13-15. 
nią, wskazuje na pewien proces, w którym z konieczności jakimś poszczególnym etapom należy przypisać adekwatne do nich pewne stany świadomości. Zarówno na początku drogi, jak i u jej celu muszą istnieć, jak się wydaje, dwa powiązane ze sobą rodzaje stanów świadomości. Można odgórnie przyjąć, że musi to być pewien habitualny stan świadomości, czyli jakiś charakterystyczny sposób bycia, któremu towarzyszy powtarzające się określone przeżywanie świata i własnego podmiotowego jestestwa charakterystyczne dla danego etapu drogi duchowej. Wspomniana kwestia oraz rozważany tu problem wymagają przedstawienia zagadnienia świadomości.

\section{Charakterystyka zagadnienia świadomości}

Wskazane kwestie dotyczą zagadnienia świadomości, szczególnie samoświadomości jako wiedzy o sobie samym a zarazem elementu kluczowego dla tego, który podejmuje wysiłek doskonalenia duchowego. Rozważane zagadnienie jest czymś niezależnym od danej denominacji religijnej, co oczywiście formalnie wpisuje się bardziej w zakres duchowości współczesnej, choć może pełnić funkcję deskryptywną lub wyjaśniającą dla duchowości w ogóle. Ogólna charakterystyka podkreśla, że świadomość to poczucie ,przeżywania lub doznawania, obecności czy zachodzenia czegoś. [...] Specyficzna dla człowieka cecha przeżycia, ujawniająca się jako doznanie określonej treści”'13. Józef Dębowski wskazuje, że to taki typ zjawisk i procesów psychicznych, które przejawiają się $\mathrm{w}$ przytomnym przeżywaniu treści przedmiotowych $\mathrm{w}$ szerokim zakresie, począwszy od prostych wrażeń i percepcji, aż po aktywność abstrakcyjno-pojęciową. Wspomniany autor zauważa także, że świadomość „stanowi najwyższą formę integracji życia osobowego człowieka. Współorganizuje jego wszechstronną aktywność życiową i jest podstawowym regulatorem jego zachowania: poznania i działania"14. Świadomość jest czymś podstawowym odnośnie do całokształtu zachowań i postaw jednostki, gdyż jak czytamy w innym miejscu: „stanowi najwyższy poziom regulacji zachowania człowieka i ujawnia się jako specyficznie wewnętrzne, dostępne bezpośrednio tylko podmiotowi poznanie otoczenia, własnej osoby oraz relacji podmiot-otoczenie"15. Kwestia wskazanej regulacji dotyczy trzech wymiarów świadomości wzajemnie ze sobą powiązanych, mianowicie: (a) świadomości percepcyjnej - reprezentującej otoczenie za pomocą obrazów; (b) świadomości abstrakcyjnej - pojęciowo-symbolicznej

13 A. Podsiad, Z. Więckowski, Mały słownik terminów i pojęć filozoficznych, Warszawa 1983, kol. 385 .

14 J. Dębowski, Świadomość, w: J. Dębowski i in., Mała encyklopedia filozofii, Bydgoszcz 1996, s. 460.

15 A. Podsiad, Z. Więckowski, Maty słownik terminów..., dz. cyt., kol. 386. 
reprezentacji otoczenia; (c) samoświadomości - będącej zwrotną reprezentacją własnych niższych warstw świadomości. Powyżej wymienione wymiary stanowią treść świadomości, która jawi się jako zorganizowana w postaci strumienia aktów oraz zarazem wskazuje na podmiot tych aktów jako niezbywalny i niesamodzielny moment każdego aktu bądź przeżycia intencjonalnego przysługujący pewnemu „Ja"16. Zatem zagadnienie świadomości można sprowadzić do strumienia następujących po sobie aktów dotyczącego wymienionych różnych sfer struktury bytowej człowieka, które są „powielane” i mają określoną budowę. Charakterystyka pojedynczego aktu świadomości pozwala wyróżnić kilka jego najważniejszych elementów składowych ${ }^{17}$ :

- treść intencjonalną - odnoszącą się do „czegoś”;

- moment intencji - czyli przedmiot tego odniesienia;

- jakość aktu - sposób odniesienia do przedmiotu (np. wyobrażenie, spostrzeżenie, przypomnienie);

- egotyczną orientację - przysługującą konkretnemu podmiotowi, która jest aktem podmiotu;

- moment przeżywania - samoświadomość właśnie spełnianego aktu przez podmiot.

Wymienione cechy pojedynczego aktu wskazują w pewnym uogólnieniu na trzy elementy będące we wzajemnym bliskim stosunku do siebie, mianowicie podmiot, przedmiot oraz samoświadomość. Kluczową cechą jest samoświadomość, gdyż - jak się wydaje - stanowi „To” podmiotu, czyli jeśli chcemy w sposób adekwatny wskazać na jakiś desygnat słowa ,podmiot”, to musimy się odwołać do samoświadomości, gdyż właśnie w tym wymiarze dokonuje on samookreślenia. Zasadniczo samoświadomość jest aktem świadomości, gdzie przedmiotem dla podmiotu jest sam podmiot, wskazuje na to wyraźnie Karen Gloy. Autorka ta, rozważając zagadnienie samoświadomości, stwierdza, że jest to „samoujęcie świadomości”" Jeśli przyjrzymy się temu zagadnieniu w jego ogólnej charakterystyce, to możemy powiedzieć, że w samoświadomości dochodzi do bezpośredniego i pierwszoosobowego poznania własnych stanów świadomych ${ }^{19}$. Ponadto, w niej ujawnia się świadomość „Ja”, która ma zwrotny charakter. Jest obecna sama dla siebie oraz odnosi siebie nie tylko do swoich przedmiotów i procesów ich poznania, ale także wyraźnie wyodrębnia się od tego wszystkiego, czym „Ja” nie jest ${ }^{20}$. Najczęściej wskazuje się na następujące typy samoświadomości:

16 Tamże; J. Dębowski, Świadomość, dz. cyt., s. 460.

${ }_{17}$ R. Poczobut, Rodzaje samoświadomości, „Analiza i Egzystencja” nr 7 (2008), s. 11.

${ }_{18}$ K. Gloy, Wprowadzenie do filozofii świadomości, thum. T. Kubalica, Kraków 2009, s. 64.

19 R. Poczobut, Rodzaje samoświadomości, dz. cyt., s. 10.

${ }^{20} \mathrm{H}$. Vorgrimler, Nowy leksykon teologiczny. Wiara - objawienie - dogmat, thum. i oprac.

T. Mieszkowski, P. Pachciarek, Warszawa 2005, s. 327. 
- spostrzeżenie wewnętrzne - świadomość w formie zorganizowanej aktowo stanów świadomych lub innych czynności;

- retrospekcję - uwzględnia użycie pamięci, świadomość w formie zorganizowanej aktowo minionych stanów świadomych lub innych czynności;

- spostrzeżenie immanentne - to spostrzeżenie wewnętrzne zmodyfikowane za pomocą redukcji fenomenologicznej;

- proste przeżywanie - nieaktowy element każdego aktu świadomości ${ }^{21}$.

Szczególnie istotny jest typ ostatni spośród tu wymienionych, gdyż tym, co go wyróżnia od pozostałych trzech, jest nieaktowy charakter. Wskazana cecha ma zasadnicze znaczenie, gdyż odsłania nam ,najbardziej pierwotny” podmiot. Trzy pierwsze typy samoświadomości z tego względu, że mają postać aktu, są aktami świadomości, co do zasady podobnymi do wszystkich innych, natomiast proste przeżywanie (także określane jako przeżywanie, intuicja przeżywania lub aktualne „Ja”), choć formalnie i z konieczności należy do stanów świadomych podmiotu, to jednak ma odmienną specyfikę, jak się wydaje, nadrzędną. Renata Ziemińska, dokonując charakterystyki natury tego typu samoświadomości, uwypukla jego zasadniczą rolę i przyczynowy charakter. Stwierdza bowiem, że „ten nieaktowy moment wszystkich aktów i stanów świadomych" powoduje, że „są one «świadome»” oraz „,w prosty sposób ujawnia podmiotowi te akty i stany w trakcie ich zachodzenia"22. Problem jest tego rodzaju, że typ ten nie może podlegać badaniu inaczej jak w formie minionej w postaci autorefleksji. Cytowana autorka, dokonując pewnego uzasadnienia, pisze że: „Aktualne ja i aktualna intuicja przeżywania są nieuchwytne, ponieważ to one dokonują wszelkich poznawczych uchwyceń" ${ }^{\prime 2}$. Jest tak, gdyż są już treścią kolejnego aktu, ponieważ: „W momencie próby uchwycenia aktualnego ja i jego aktualnej intuicji przeżywania, para ta natychmiast przenosi się na poziom wyższy i reflektuje swoją właśnie minioną fazę"24.

Oznacza to utworzenie się kolejnego aktu, któremu niezbywalnie i koniecznie towarzyszy już wskazywany rodzaj nieaktowej samoświadomości. Dla pewnego porządku należy powiedzieć, że pojawia się kolejny akt świadomości będący aktem samoświadomości ze względu na swoją treść, któremu towarzyszy wspomniany element, czyli samoświadomość nieaktowa. Analiza

${ }^{21}$ R. Poczobut, Rodzaje samoświadomości, dz. cyt., s. 10.

${ }^{22}$ R. Ziemińska, Samoświadomość i samowiedza z punktu widzenia epistemologii, „Analiza i Egzystencja" nr 7 (2008), s. 39. A. Podsiad wskazuje także na akty świadomości, które mają charakter nieaktowy, mianowicie należą do nich $\mathrm{m}$. in.: nastrój, bierne doznawanie wrażeń czy świadomość tła dla każdego aktu, przy braku odniesienia do siebie, czyli braku samoświadomości. Zob. A. Podsiad, Z. Więckowski, Mały stownik terminów..., dz. cyt., kol. 386.

${ }^{23}$ R. Ziemińska, Samoświadomość $i$ samowiedza..., dz. cyt., s. 39.

${ }^{24}$ Tamże. 
tej kwestii i dokonanie dalszych precyzacji pozwala stwierdzić za Robertem Poczobutem, że to proste przeżywanie lub intuicja przeżywania ,jest immanentnym momentem aktualnie spełnianego aktu świadomości”, czyli pojawia się wraz z każdym aktem; natomiast świadomość zorganizowana na sposób aktowy ujawnia swą dwubiegunowość - ,jest jednocześnie zorientowana przedmiotowo i samozwrotna”, co oznacza przeżywanie aktów świadomości jak również zachodzenie innych doznań i nastrojów, mających nieaktowy charakter ${ }^{25}$. Cytowany autor podkreśla rolę samoświadomości nieaktowej: „Przeżywanie stanowi świadomościową (subiektywną, podmiotową) stronę wszelkich aktów świadomych. Bez momentu przeżywania w ogóle nie byłoby świadomości - co najwyżej nieświadomy odbiór i przetwarzanie informacji przez wyspecjalizowane ośrodki (moduły) naszego mózgu" "26.

Jak wynika z powyższego, mamy taką sytuację, że w porównaniu do przedstawionego aktu samoświadomości pojawia się podmiot nieempiryczny. Zostało tu zaakcentowane przeżywanie, czyli aktualne „Ja”, które z jednej strony traktowane jest jako element niezależny od strumienia zmieniających się par podmiotowo-przedmiotowych, ale z drugiej ujawnia się właśnie dzięki tym parom.

Wskazany wcześniej podział ${ }^{27}$ składa się z podmiotu empirycznego związanego ze zmieniającą się przedmiotową treścią oraz elementu decydującego, będącego samym poznawaniem, którego treścią jest swój własny zmieniający się w czasie podmiotowo-przedmiotowy związek. Pojedynczy akt świadomości tworzą przedmiot i podmiot oraz element samoświadomości, inaczej mówiąc, podmiot empiryczny, jego przedmiotowe dopełnienie oraz podmiot „właściwy” jako aktualne „Ja”, mający charakter nadrzędny i przyczynowy, który najbardziej ujawnia się i jedynie pośrednio w sekwencji podmiotowo-przedmiotowych aktów, w których podmiot odnosi się do siebie.

Analogiczną do aktu świadomości strukturę podmiotowo-przedmiotową ma akt poznawczy, co w zasadzie czyni je nieodróżnialnymi od siebie i wobec kwestii tu rozważanych ujawnia interesującą zależność. Charakterystyka zaprezentowana przez Leona Wciórkę przedstawia związek ze świadomością oraz ujawnia, że podmiot w swym akcie poznania zmienia się na rzecz istniejącego w nim przedmiotu intencjonalnego. Akt poznawczy składa się z podmiotowo-przedmiotowej relacji teoriopoznawczej umożliwiającej poznanie danego przedmiotu transcendentnego wobec podmiotu. Kluczowym momentem tego procesu jest ujęcie tegoż przedmiotu przez podmiot i jego istnienie na sposób intencjonalny. Wspomniany autor, odnosząc się do istoty ludzkiego

\footnotetext{
${ }^{25}$ R. Poczobut, Rodzaje samoświadomości, dz. cyt., s. 13.

${ }^{26}$ Tamże, s. 13-14.

27 Por. wyżej.
} 
poznania, wskazuje, że relacja ta ,polega [...] na zjednoczeniu przedmiotu poznawanego z podmiotem poznającym" 28 . W innym miejscu dookreśla naturę tejże relacji, stwierdzając, że:

Jest to relacja szczególnego rodzaju. Polega bowiem na pewnym nowym, specyficznym dla czynności poznawczej sposobie istnienia przedmiotu poznawanego $\mathrm{w}$ podmiocie poznającym. Podmiot poznający wykonując akt poznania zmienia się, bo rzecz poznawana zaczyna w nim istnieć istnieniem właściwym mu jako podmiotowi. Inaczej mówiąc, jako przedmiot poznania w podmiocie się uobecnia ${ }^{29}$.

Zatem podmiot istnieje w akcie na sposób ujmowanego przedmiotu. Ostatnia uwaga wydaje się równie interesująca, gdyż sposób ujęcia przedmiotu określa sam podmiot. Autor ten, konkludując swoje rozważania na temat struktury aktów poznawczych i procesu poznania, ujawnia ścisły związek poznania i świadomości oraz immanentną naturę tego procesu: „Stwierdzenie, iż istota poznania ludzkiego sprowadza się ostatecznie do intencjonalnego zaistnienia przedmiotu poznanego w podmiocie poznającym, akcentuje immanentny charakter poznania. Nic nie może więc być poznane, co nie stanie się wewnętrznym przeżyciem świadomości” ${ }^{30}$. Przedstawiona przez L. Wciórkę struktura aktu poznawczego i główne elementy procesu poznania wskazują na pewnego rodzaju zawłaszczenie podmiotu przez przedmiot oraz na określoną kondycję podmiotu, który sam sprawia, że ujęcie jest właśnie takie. Charakterystyka ta kładzie akcent na funkcję poznawczą właściwego podmiotu, który poznaje za sprawą własnych podmiotowo-przedmiotowych ujęć, zaś takie ujęcie zakrywa bądź może zakrywać, niejako zawłaszczać ów właściwy podmiot. W kontekście rozważań nad samoświadomością Karen Gloy zauważa, że taka sytuacja zawłaszczenia ma miejsce wtedy, gdy następuje zapomnienie o sobie a samoświadomość zostaje utracona. Autorka formułuje swoją definicję samoświadomości na podstawie świadomości różnicy między „Ja” i „nie-Ja”, czyli między „Ja” a tym, co się jawi przedmiotowo w stosunku do niego. Jeśli ta różnica nie jest doświadczana, to jest to jednoznaczne z brakiem samoświadomości. Autorka ta pisze: „Jak długo człowiek zapomina o sobie i naiwnie oddaje się światu, jego Ja rozmywa i rozpływa się w świecie. Wraz ze zwrotem do siebie i powstaniem świadomości różnicy względem świata rodzi się w nim również samoświadomość; tak iż obydwa zjawiska idą ręka w rękę" "31. Uwaga poczyniona przez K. Gloy wskazuje nam również nie tylko na mechanizm

\footnotetext{
${ }^{28}$ L. Wciórka, Teoria poznania, Biblioteka Pomocy Naukowych, t. 8, Poznań 1996, s. 23.

29 Tamże, s. 22.

${ }^{30}$ Tamże, s. 23.

${ }^{31}$ K. Gloy, Wprowadzenie do filozofii świadomości, dz. cyt., s. 72.
} 
wzrostu, oddzielania „Ja” od „,nie-Ja”, lecz ujawnia, że podmiot empiryczny wraz ze zwrotem do siebie wyodrębnia się jako poznający, który jedynie stawia sobie naprzeciw to, co poznawane, lecz już mu nie podlega. Jednak tak rodząca się i wzrastająca samoświadomość podmiotu może się zrealizować tylko dzięki istnieniu aktów o dualnym podmiotowo-przedmiotowym charakterze. Dokonana charakterystyka prowadzi do stwierdzenia, że podmiot empiryczny bez elementu samoświadomości zostaje „zawłaszczony” przez aktualną treść przedmiotową, gdyż treść przedmiotowa jako przedmiot intencjonalny w taki sposób oddziałuje na podmiot empiryczny.

Poczyniona charakterystyka zagadnienia świadomości pozwoli przyjrzeć się, jak należy rozumieć rozwój duchowy, w jaki sposób się na tej podstawie dokonuje, i wskazać na potencjalne obszary doskonalenia i wzrostu.

\section{Rozumienie rozwoju duchowego na gruncie zagadnienia świadomości}

Dokonana charakterystyka świadomości pozwala wyróżnić trzy elementy strukturalne, które składają się na pojedynczy akt świadomości, mianowicie: (1) podmiot empiryczny, poznający; związany ze swoim (2) przedmiotowym dopełnieniem, inaczej treścią przedmiotową, poznawane, to także przedmiot intencjonalny aktu poznawczego mający taką samą budowę. Ponadto postulowany jest element trzeci, który ujawnia się, gdy formalnym przedmiotem aktu świadomości jest sam podmiot, stając się de facto aktem samoświadomości. Element ten (3) przybiera, w zależności od kontekstu, narracji lub pełnionej funkcji, różne nazwy: samoświadomość nieaktowa, nieempiryczny moment podmiotu, podmiot nieempiryczny, aktualne „Ja”, to, co poznaje w akcie poznawczym. Odmienność nazw wynika również z tego względu, że narracja o świadomości może być prowadzona przedmiotowo, czyli poprzez formalne wyliczenie elementów składowych i ich wzajemnych zależności, oraz podmiotowo, czyli z perspektywy tego, jak ,jawi się” to, co jest doświadczane, niejako pierwszoosobowo.

Wskazany podział na podmiot empiryczny i podmiot „właściwy” jest nieco mylący. Podmiot jest jeden i wyłącznie dzięki spekulatywnemu namysłowi oraz samoobserwacji da się wskazać na jego empiryczny i nieempiryczny moment. Podejście bardziej realistyczne i „oddolne” za punkt wyjścia bierze podmiot empiryczny, natomiast właściwy podmiot, aktualne „Ja”, czyli samoświadomość nieaktowa, jest jedynie koniecznym dopełnieniem sekwencji aktów, która ukazuje się jako ściśle zależna od kolejnych aktów, gdyż powstaje wraz z każdym aktem. Natomiast podejście bardziej idealistyczne, „odgórne”, akcent kładzie na moment nieempiryczny, co powoduje, że sekwencja aktów jedynie ujawnia istniejącego, natomiast jego związek, choć konieczny w tej funkcji, jest czymś wtórnym. Mało tego, należy wskazać, 
że dzięki takiemu podejściu jest możliwy przeskok na wyższy poziom, gdzie moment empiryczny przedmiotu da się spekulatywnie uprzedmiotowić, wtedy samoświadomość nieaktowa, aktualne „Ja” zyskuje niezależność i samoistność, gdzie to, co empiryczne, ostatecznie jedynie ,przydarza się”.

Przedstawiona charakterystyka dokonuje pewnego rodzaju „cofania się w głąb”, co ma na celu uchwycenie wymiaru, który ma charakter nadrzędny lub przyczynowy. Oczywiście, rozważana rola świadomości w procesie rozwoju duchowego nabiera szczególnego znaczenia w przypadku przedmiotów doświadczenia wewnętrznego, czyli, inaczej mówiąc, aktowo zorganizowanych podmiotowo-przedmiotowych własnych wytworów, które mają dualistyczną strukturę, tworzą akt poznawczy i uczestniczą w procesie poznania. Tutaj ujawnia się właściwa rzeczywista trudność z wyodrębnianiem się „Ja”, a zarazem związana z tym możliwość rozwoju. Wobec przedmiotów doświadczenia zewnętrznego powstanie samoświadomości, czyli świadomości różnicy podmiotu w stosunku do tego typu obiektów następuje natychmiastowo, mimo częstego „odurzania” światem, zawłaszczenia przez niego, połączonego z zapominaniem o sobie. Natomiast w przypadku doświadczeń wewnętrznych, czyli wskazanych wcześniej pojęciowo-symbolicznych prezentacji, wyodrębnianie się ,Ja” $\mathrm{z}$ własnych wytworów jest złożone i ma charakter procesu. Należy je postrzegać jako zadanie, które, jak się wydaje, ma dwa etapy. Pierwszy dotyczy zbudowania koncepcji „Ja”, pojęciowego określania, czyli budowania światopoglądu i kultywowania przekonań o sobie, z którymi podmiot się utożsamia, za pomocą których się wyraża oraz w których się, póki co, „odbija”. Natomiast etap drugi związany jest z odkrywaniem prawdziwego „Ja” pośród wytworzonych i wytwarzanych „obrazowań siebie”. Ten właśnie etap należy postrzegać jako swoistą zdolność, powodującą ujawnianie się samoświadomości w formie nieaktowej, która wraz z rozwojem jest coraz większą świadomością różnicy wobec tego, co ma formę aktową - podmiotowo-przedmiotową. Jeśli w tych aktach podmiot odnosi się do siebie, to jest to jeden z typów samoświadomości aktowej, które są jednak wtórne wobec samego podmiotu, gdyż sam je tworzy. Trudność w pojawieniu się (a raczej jej dostrzeżeniu lub rozpoznaniu) samoświadomości nieaktowej polega na tym, że samoświadomość aktowa ma charakter konceptualny, czyli de facto konceptualne „Ja”, „zakrywa” prawdziwe „Ja”. Jednak nie to jest problemem, że w ogóle taki proces ma miejsce, gdyż jest naturalnym etapem rozwoju, lecz wspomnianą trudność tworzy uporczywość trwania podmiotu w takim postrzeganiu siebie i identyfikowaniu się z nim.

Konstytuowanie się podmiotu zachodzi dzięki przedmiotowi, który się jawi w polu świadomości jako jego ,nie-Ja”. Kwestia ta jest widoczna, gdy rozważamy strukturę aktu poznawczego, gdzie podmiot konstytuuje się, doznając przedmiotu, i wraz ze zwrotem do siebie konstytuuje się jako „Ja” 
poprzez „bycie naprzeciw” wszelakiej przedmiotowej treści, którą ujmuje. Można powiedzieć, że jest to pewnego rodzaju nieempiryczny moment obdarzony poznaniem nadbudowany nad tym, co empiryczne, manifestujący się wraz z konstytuowaniem się podmiotowo-przedmiotowego aktu świadomości. Ów podmiot empiryczny trwa, aktualizując się wraz z każdym aktem za sprawą swojego dopełnienia, czyli przedmiotowej treści. Oczywiście ten moment, będący samym poznaniem, tyczy się właściwego podmiotu (podmiotu nieempirycznego), gdzie przeziera on poprzez poszczególne akty w formie samoświadomości nieaktowej.

W kwestii wyrażenia skutków rozwoju możemy posłużyć się pojęciem bardziej ogólnym od pojęcia samoświadomości, mianowicie pojęciem samopoznania. Korzystając z charakterystyki przedstawionej przez R. Poczobuta ${ }^{32}$ dotyczącej tego zagadnienia, należy stwierdzić, że samopoznanie jest czynnością pozyskiwania informacji o sobie bądź jest to wytwór tej czynności. Ponadto, wskazana czynność może odbywać się z udziałem świadomości lub podprogowo oraz ma charakter procesu dokonującego syntezy z ujęć cząstkowych, która następnie zostaje wyrażona za pomocą odpowiednich autoprezentacji: wyobrażeń, pojęć, sądów, modeli wytworzonych przez podmiot. Samopoznanie w swym aspekcie wytwórczym stanowi przejawienie za sprawą aktów świadomości mające pewną poznawczą jakość i treść oraz, co należy przyjąć, pewien stan habitualny, określone rozumienie siebie, które następnie zostaje wyeksplikowane za pomocą języka. Ten ostatni aspekt dotyczy już samowiedzy będącej skutkiem samopoznania, która winna spełniać według cytowanego autora pewne kryteria: (a) zdolność do pojęciowej kategoryzacji własnych stanów wewnętrznych winna być odpowiednio uzasadniona oraz (b) być prawdziwa lub przynajmniej podmiot musi mieć mocne przekonanie o prawdziwości tej wiedzy ${ }^{33}$. Jednak sama autoprezentacja jest już, czymś wtórnym. Jest co prawda aktowym stanem świadomości, ale zawiera określone ,przedstawienie" siebie, czyli pewną aktową formę rozumienia siebie przez podmiot, której treść powinna stawać się bogatsza wraz postępem podmiotu.

Na podstawie powyższych rozważań zasadniczo możemy wyróżnić następujące trzy elementy, mianowicie:

- element nadrzędny, będący również celem do odkrycia: samoświadomość nieaktowa, aktualne „Ja” lub krótko „Ja”, nieempiryczny lub „właściwy” podmiot, poznanie (czysta gnosis) w akcie poznawczym

\footnotetext{
${ }^{32}$ R. Poczobut, Rodzaje samoświadomości, dz. cyt., s. 6-7.

33 Tamże, s. 8.
} 
oraz świadomość różnicy w przedstawionej definicji samoświadomości zaprezentowanej przez K. Gloy;

- pierwsza składowa aktu (poznawczego, świadomości): podmiot empiryczny lub krótko podmiot, świadomość, poznający;

- druga składowa tegoż aktu, konieczne dopełnienie pierwszej składowej: wszelka przedmiotowa treść, czyli, po prostu przedmiot lub przedmiot intencjonalny, poznawane.

Podmiot wzrasta w swojej samoświadomości, różnicując się wobec rozmaitych obiektów, czemu towarzyszy rozumienie siebie jako „Ja”. Oczywiście, owo „Ja” jest początkowo bardzo mgliste i prawie nie „widzi siebie” lub widzi jego peryferie. Rozwój duchowy jest procesem wzrostu samoświadomości i konstytuowania się „Ja” jako podmiotu empirycznego, które dokonuje wyodrębnienia siebie z określonej klasy obiektów będących składową pola możliwego doświadczenia przysługującego człowiekowi. Proces ten dotyczy podmiotu empirycznego, gdyż w każdym momencie swojego istnienia jest ukonstytuowany na zasadzie relacji podmiotowo-przedmiotowej, natomiast wzrastanie ostatecznie polega na odkrywaniu siebie poprzez wyodrębnianie się aktywności samego „Ja” wraz z wyróżnianiem się określonych obiektów i separacją od nich. Z tej perspektywy swoista droga rozwoju w zaprezentowanej tutaj formie jest konstytuowaniem się „Ja” polegającym na wyodrębnianiu się siebie z obiektów możliwego pola doświadczenia oraz umacnianiu takiego rdzenia w sobie, w którym zrozumienie siebie i swoich aktów występuje w postaci zdolności podlegającej stałemu wzrostowi. Zasadniczo oznacza to zdolność do uprzedmiotowiania własnych wytworów, czegokolwiek one dotyczą. Najpierw dotyczy to poziomu obiektów zmysłowych w całej swej rozciągłości, a następnie zdolność ta „zmierza” coraz bardziej „w głąb” siebie po doświadczenia wewnętrzne aż do pojawienia się i pojawiania się („bycia świadomym") samoświadomości nieaktowej. Miarą rozwoju duchowego jest zdolność do wyodrębniania się „Ja” wobec określonych przedmiotów, a konkretnie do samoświadomości podmiotu w różnego typu aktach świadomości, który dąży (lub powinien dążyć) do powstania samoświadomości nieaktowej i jej trwałej obecności we wszystkich aktach pojawiających się w strumieniu świadomości. Podmiot ,właściwy” jest nierozdzielny od podmiotu empirycznego, gdyż do swojego ukonstytuowania, potrzebuje przedmiotowej strony w relacji teoriopoznawczej. Wynika to także ze stanu podmiotu przebywającego w stanie samoświadomości nieaktowej, ponieważ samoświadomość nieaktowa ujawnia się dzięki stanowi świadomości, który ma charakter aktowy, czyli podmiotowo-przedmiotowy.

$\mathrm{Na}$ zakończenie niniejszych rozważań należy jeszcze wskazać ogólnie rolę, jaką może odgrywać przedstawione tu zagadnienie świadomości zarówno w duchowości tradycyjnej, jak i duchowości współczesnej. W przypadku 
duchowości tradycyjnej, instytucjonalnej, która bazuje na terminach ontologicznych i pozapodmiotowych, rozważane tu zagadnienie świadomości może pełnić jedynie funkcję pomocniczą - dookreślającą. Ze względu na zdefiniowany $\mathrm{w}$ tym typie duchowości $\mathrm{w}$ terminach ontologicznych cel soteriologiczny oraz przedmiot religijny (sacrum), zachodzi konieczność przekładania terminologii ontologicznej na teoriopoznawczą wraz z zachowaniem sensu i wskazaniem na większe znaczenie tej pierwszej. W przypadku duchowości współczesnej kategoria świadomości odgrywać może dwojaką rolę, jako konkretna propozycja rozwoju duchowego należąca do duchowości współczesnej bądź pełnić funkcję analogiczną jak w przypadku duchowości tradycyjnej, czyli dookreślać znaczenie terminów na gruncie jakiejś koncepcji rozwoju duchowego wpisującej się w kategorię duchowości współczesnej.

SPIRITUAL DEVELOPMENT FROM THE PERSPECTIVE OF CONSCIOUSNESS. OUTLINE OF THE PROBLEM

Summary

The article focuses on the issue of spiritual development from the perspective of consciousness. The question of spiritual development exists in close connection with the concept of spirituality. The issue of consciousness can be reduced to three elements that make up a single act of consciousness: an empirical subject, complementing the object, and a non-act self-awareness, i.e. a non-empirical or proper subject. Self-awareness plays a key role in spiritual development in the field of consciousness. The development of self-awareness should strive to reveal non-act self-awareness, but it has a similar structure and is experienced like any other acts of awareness. Spiritual development is the process of the of self-awareness growth and the constitution of the "Self" as an empirical subject that separates itself from a specific class of objects that are a component of the field of possible experience for a person. The effects of spiritual development can also be described as self-knowledge, which can be a conceptual explanation of either actual experiences or a more stable state of the human subject.

Keywords: consciousness; self-awareness; the Self; spirituality; spiritual development; cognition

Słowa kluczowe: świadomość; samoświadomość; „Ja”; duchowość; rozwój duchowy; poznanie 


\section{BIBLIOGRAFIA}

Baniak J., Wprowadzenie. Wielowymiarowość i konteksty kulturowe duchowości religijnej a inne formy duchowości, w: Duchowość religijna jako droga wewnętrznego doskonalenia wspótczesnego człowieka zachodniego chrześcijaństwa, red. J. Baniak, Torun 2012, s. 7-19.

Brzozowski T.T., Religijność czy duchowość? O strukturze przeżyć wewnętrznych człowieka, w: Duchowość religijna jako droga wewnętrznego doskonalenia współczesnego czlowieka zachodniego chrześcijaństwa, red. J. Baniak, Toruń 2012, s. 267-291.

Chmielewski M., Vademecum duchowości katolickiej-101 pytań o życie duchowe, Lublin 2004.

Dębowski J., Świadomość, w: J. Dębowski i in. Mała encyklopedia filozofii, Bydgoszcz 1996, s. $460-461$.

Dębowski J., Samoświadomość, w: J. Dębowski i in. Mała encyklopedia filozofii, Bydgoszcz 1996, s. 417.

Jarosz M., Pojęcie duchowości w psychologii, w: Studia z psychologii w KUL, t. 16, red. O. Gorbaniuk $\mathrm{i}$ in., Lublin 2010, s. 9-22.

Gloy K., Wprowadzenie do filozofii świadomości, tłum. T. Kubalica, Kraków 2009.

Kłoczowski J. A., Czym jest duchowość? - kontekst religijny i kulturowy, w: Fenomen duchowości, red. A. Grzegorczyk, J. Sójka, R. Koschany, Poznań 2006, s. 13-20.

Leksykon duchowości katolickiej, red. M. Chmielewski, Lublin-Kraków 2002.

Moskal P., Problematyka filozofii duchowości, w: Duchowość religijna jako droga wewnętrznego doskonalenia współczesnego człowieka zachodniego chrześcijaństwa, red. J. Baniak, Toruń 2012, s. 39-48.

Poczobut R., Rodzaje samoświadomości, „Analiza i Egzystencja” nr 7 (2008), s. 5-31.

Podsiad A., Więckowski Z., Mały stownik terminów i pojęć filozoficznych, Warszawa 1983.

Socha P., Psychologia rozwoju duchowego, w: Duchowy rozwój czlowieka, red. P. Socha, Kraków 2000, s. 15-44.

Vorgrimler H., Nowy leksykon teologiczny, thum. i oprac. T. Mieszkowski, P. Pachciarek, Warszawa 2005.

Wciórka L., Teoria poznania, Biblioteka Pomocy Naukowych, t. 8, Poznań 1996.

Wysocki A., Rozwój duchowy czlowieka w świetle pogladów św. Jana od Krzyża, w: Wychowanie do dialogu, red. K. Rędziński, Częstochowa 2008, s. 69-92.

Zaborowski Z., Teoria treści i formy samoświadomości, Warszawa 2000.

Ziemińska R., Samoświadomość i samowiedza z punktu widzenia epistemologii, „Analiza i Egzystencja" nr 7 (2008), s. 33-51.

Adam Wysocki - doktor nauk humanistycznych w zakresie filozofii (2014). Absolwent Wydziału Nauk Społecznych Uniwersytetu im. Adama Mickiewicza w Poznaniu. Studiował także teologię na Wydziale Teologicznym na UAM, a od 2016 roku jest wykładowcą tegoż Wydziału. Jego zainteresowania badawcze obejmują: filozofię religii, komparatystykę religijną, dialog międzykulturowy oraz międzyreligijny. Zajmuje się także zagadnieniami duchowości w systemach filozoficzno-religijnych Wschodu i Zachodu. Autor artykułów w czasopismach naukowych i fachowych dotyczących filozofii religii, dialogu międzyreligijnego oraz duchowości. 